\title{
COMMENTS
}

\section{ASCAP AND THE ANTITRUST LAWS: THE STORY OF A REASONABLE COMPROMISE*}

\begin{abstract}
A
ITHOUGH protected from the beginning against unauthorized reproduction of their artistic creations, ${ }^{1}$ the author and composer have traditionally found it difficult either to retain the various rights of copyright in their creations or, if these rights were retained, to enforce them against infringing users. ${ }^{2}$ As a result, recent times have seen creators join together in order to obtain a fairer share of the revenue derived from their works. ${ }^{3}$

Such groups of creators have been confronted with two basic and
\end{abstract}

* This comment was adapted from a paper entered in the Nathan Burkan Memorial Competition by Richard W. Ergo, LL.B. 1958, Duke University, while he was a thirdyear student in the School of Law. Mr. Ergo is now a member of the Washington bar and is associated with Holman, Michelwait, Marion, Black \& Perkins, Seattle, Washington.

${ }^{2}$ The Constitution, art. $\mathrm{I}, \S 8$, authorizes Congress "To promote the Progress of Science and useful Arts by securing for limited Times to Authors and Inventors the exclusive Right to their respective Writings and Discoveries." Under the original copyright statute, a copyright owner's rights included only the rights to print, publish, and vend the copyrighted composition, that is, to make and sell copies of the work. Act of May 31, 1790, I Stat. 124. Copyright rights were extended under the Copyright Act of 1909 , 17 U.S.C. $\$$ I (1952), however, to include also the right to make new arrangements or adaptations of the work, the right to have it recorded for electrical or mechanical reproduction, and the right to perform it publicly for profit.

${ }^{3}$ Klein, Protective Societies for Authors and Creators, 2953 Copyright Problems ANALYZED 19, 20 (C.C.H. r 053 ), recites almost incredible examples of typical treatment of the artistic creator by publishers during the nineteenth century which forced him 'to overcome his natural tendency to be a 'loner,' and induced him to join his fellow writers.in order to survive." A discussion of the creator's traditional inability to enforce his copyright rights and of the tremendous effect of recent radically changing conditions in the music entertainment field is found in Finkelstein, Antitrust Laws and the Arts, to Conference on the Arts, Publishing and the law 55 (University of Chicago Law School, May 5, 1952); and in Finkelstein, The Composer and the Public Interest-Regulation of Performing Right Societies, 19 LAW \& ConTEMP. Prob. 275 (1954).

${ }^{3}$ The protective societies that have been organized by creators are extremely numerous. Most of them are concerned only with protecting against violations of creators' statutory rights; a few others have the purpose of advancing creators' interests in their relations with users. Some of the latter, such as ASCAP, are combinations of creators and publishers concerned with ultimate users of artistic products; others, such as Songwriters' Protective Association, are organized primarily to advance creators' interests in their relations with the publishers. See Klein, supra note 2. 
frequently conflicting principles of permissible business activity in a democratic society. No democratic society, on the one hand, can question that literary and artistic products should be given sufficient legal protection to encourage their creation and development. On the other hand, it is just as essential an element of a democratic society that artistic products be used in the freest possible manner and with the fewest possible restraints, public or private. Thus, while the protections given or permitted must be adequate, the law should not sanction obstructions to general use and enjoyment of artistic creations at a fair cost. The interaction of those two principles is nowhere better illustrated in reference to creators' protective societies than in the history and development of the most significant of these groups--the American Society of Composers, Authors, and Publishers (ASCAP).

\section{ASCAP}

ASCAP is an organization dealing exclusively in the licensing of copyright performing rights. That is, the only copyright right which it licenses is that of public performance for profit. Its membership, as the name implies, comprises authors and composers of musical compositions and publishers of such compositions. Although the relationship between these two dissimilar groups of members has often been tenuous, the memory of past individual helplessness has been a cementing force holding the organization together and permitting it to achieve and maintain its present prominence.

ASCAP's beginning can be traced to a night in 1913 in a New York restaurant, when composer Victor Herbert heard an unlicensed performance of the music from one of his musical shows then playing on Broadway. ${ }^{4}$ Upon calling the attention of the proprietor to the fact that the copyright law forbade such unauthorized use of copyrighted music, Herbert was informed that since no admission was charged to enter the restaurant, no part of the copyright law was involved. In the dispute which followed, individual copyright owners, such as Herbert, became aware that individually it was physically and financially impossible for them to enforce their rights in all, or even most, instances of such infringement. Moreover, their individual weakness was further emphasized when restaurant, cabaret, and hotel owners united against the composers. Their only hope lay in a corresponding unification,

\footnotetext{
'See Allen, The Battle of Tin'Pan Alley, Harpers Magazine, Oct., 1940, p. 5 I4.
} 
and thus was born ASCAP, an association of 170 authors and composers and twenty-two publishers ${ }^{5}$ of music.

The legal offspring of this dispute, Herbert v. Shanley Co., ${ }^{6}$ upheld the right of a copyright owner to compensation for public performance of his work, even in cases involving restaurants and hotels where no admission was charged. Speaking for a unanimous Supreme Court, Mr. Justice Holmes wrote,?

The defendants' performances are not eleemosynary. They are part of a total for which the public pays, and the fact that the price of the whole is attributed to a particular item which those present are expected to order is not important. It is true that the music is not the sole object, but neither is the food, which probably could be got cheaper elsewhere. The object is a repast in surroundings that to people having limited powers of conversation or disliking the rival noise give a luxurious pleasure not to be had from eating a silent meal. If music did not pay it would be given up. If it pays it pays out of the public's pocket. Whether it pays or not the purpose of employing it is profit and that is enough.

Following this decision, the federal courts extended the concept of public performance for profit to radio broadcasts of copyrighted musical compositions, ${ }^{8}$ reproduction of radio broadcasts by loudspeakers installed in hotel lobbies, ${ }^{9}$ performances in motion picture theaters, ${ }^{10}$ and performances in dance halls. ${ }^{11}$ In the wake of these decisions, ASCAP grew to many times its original size in number of members and, at the same time, expanded internationally by affiliating with the International Confederation of Performing Right Societies, an organization which controlled twenty-one various national groups. ASCAP gained control of the great bulk of music in commercial demand ${ }^{12}$ and, at least in its

\footnotetext{
"The initial inclusion of publishers in the group was justified by the importance of their activities and their interests in the artistic products of music composers and authors. : See Chafee, Reflęctions on the Law of Copyright, 45 Colum. L. REv. 503 (1945).

242 U.S. $591(1917)$.

${ }^{7} I d$. at 594,595 .

${ }^{8}$ Witmark \& Sons v. Bamberger \& Co., 29r Fed. 4 II (6th Cir. 1925).

${ }^{\circ}$ Buck v. Jewell-ĹaSalle Realty Co., 283 U.S. 191 (r931).

${ }^{10}$ Witmark \& Sons v. Pastime Amusement Co., 298 Fed. 470 (E.D.S.C. 1924).

${ }^{11}$. Dreamland Ballroom v. Shapero, Bernstem \& Co., 35 F.2d 354 (7th Cir. 1929).

${ }^{12}$ At times it has been estimated that ASCAP has controlled anywhere from 85 to $90 \%$ of the popular and classical music of this country that has not passed into the
} 
own estimation, had become the most important performing-right society in the world. ${ }^{13}$

The organization that grew up was relatively simple in structure and operation. Originally, any professional composer or author of music who had had regular publication of five or more works with a substantial number of performances was eligible for membership, as was any publisher of music whose repertory was used by ASCAP licensees. The management of ASCAP was conducted by a twenty-four man, selfperpetuating board of directors, composed half of composer-members and half of publisher-members. The business of ASCAP was the licensing of performing rights assigned to it by its members. As a matter of policy, only blanket licenses for specific use were granted. That is, the licensee was given blanket authorization to use the entire repertory of ASCAP for such specific types of use as radio broadcasts or restaurant or dance hall performances. ${ }^{14}$ ASCAP charged an annual fee for such licenses, and this constituted its sole source of revenue.

Distribution of the revenue to its members was (and is) somewhat unique. Net proceeds were split in half between the publisher and author-composer groups, an obvious and easy initial solution. Final distribution to the individual members was by no means so easy of solution, however. Until recently, no strict formula was followed, although each member's share was generally based upon the amount of commercial performance (as determined by independent music surveys) of the member's compositions, the member's seniority in ASCAP, and the quality of the composition of each. Although the propriety of the first standard has never been questioned, there has been a great struggle between younger and older members of ASCAP over the presence of a seniority standard. Moreover, the practical difficulties involved in a subjective appraisal of the quality of any composition has given rise to the allegation that privileged insiders and unproductive writers were being permitted to take an unfair share of ASCAP's revenues.

Accompanying such internal problems, there were even more serious external disputes. Early in the life of ASCAP, a new user, radio,

public domain. See 'Timberg, The Antitrust Aspects of Merchandising Modern Music: The ASCAP Consent Judgment of 1950, 19 LAW \& CONTEMP. ProB. 294, 297 (1954).

${ }^{13}$ White, Musical Copyrights o. the Anti-Trust Laws, 30 NEB. L. REv. 50, 52 (1951), citing The Story of ASCAP (1946).

Is Licensing on the basis of individual compositions-"per piece" licensing-has never been in great demand by licensees and, moreover, is not considered commercially practicable. Finkelstein, Antitrust Laws and the Arts, supira note 2, at 58 . 
entered the music entertainment field. ${ }^{15}$ At first, ASCAP licensed embryo radio stations free of charge or at nominal fees in order to encourage and aid the financial development of potentially good customers. Shortly thereafter, as radio became a commercial success, ASCAP began to demand a share of the profits. The Federal courts having declared that radio performances of musical compositions were public performances for profit, it appeared that ASCAP could legally assess reasonable fees against radio broadcasters.

Bitter disputes between radio and ASCAP arose during the 1930's, however, over what constituted fair licensing. ${ }^{16}$ Generally, these disputes were settled by contractual agreement, ASCAP getting a fixed fee plus a percentage of the station's commercial income. But in March 1940, ASCAP proposed a substantial reduction in the rates paid by individual stations, especially smaller ones, to be more than offset by a $7^{1 / 2}$ per cent fee on the income of the networks, which had previously paid nothing. The networks rejected this offer, and both sides prepared for a conflict. The radio broadcasters insisted that submission to ASCAP's power of taxation would mean the end of an independent broadcasting industry and proceeded to abstain from all use of ASCAP music. In its stead, radio subsisted for an entire year upon music in the public domain and that controlled by Broadcast Music, Inc. (BMI), a younger performing-right society, with a much smaller and less valuable repertory, but with direct ownership connections in the radio industry.

On the other side, ASCAP stood unrelenting in its position, insisting that the new terms were equitable because (I) the increase in license fees was based upon the increase in profit to radio broadcasting, much of which was attributable to use of ASCAP compositions (2) the primary financial burden was placed upon the networks which were best able to pay, and (3) ASCAP members' losses in other royalties owing to the increased popularity of radio were far greater than any sums received from the broadcasters. ${ }^{17}$ But as a result of the public's failure to exert. pressure on the radio broadcasters to play ASCAP music and the imminence of an antitrust action, ASCAP was forced to accede to the terms of the networks. ${ }^{18}$

\footnotetext{
${ }^{25}$ See Allen, supra note 4.

${ }^{20}$ See Comment, II AIR L. REv. 395 (1940).

${ }^{27}$ The advent of successful radio and television broadcasting is said to have cut the sales of sheet music, the primary source of composers' royalties prior to the entry of these inedia, by $90 \%$. Finkelstein, Antitrust Laws and the Arts, supra note 2, at 57 .

${ }^{28}$ See White, supra note 13 , at 55 .
} 
The Consent Decree of i $94 \mathrm{I}$

Prosecution of the antitrust action continued, however. Fearing the possible disastrous consequences of a full hearing, ASCAP avoided any determination on the merits of its Sherman Act status by entering a plea of nolo contendere to the criminal charges against it. Similarly, it avoided a hearing on the merits in the civil action against it by entering into a consent decree with the Government.

This decree ${ }^{19}$ placed significant limitations upon ASCAP's future operations. In the first place, ASCAP was thenceforth enjoined from acquiring or asserting any exclusive performing rights as agent, trustee, or otherwise on behalf of any copyright owner. At the same time, however, it was permitted to place substantial limitations on the reserved individual licensing rights of its members. ASCAP could require members to pay over to it all proceeds derived from such individual issuance of performing licenses and could also prohibit members from issuing exclusive licenses to commercial users of music or from assigning their rights to any other performing-right society. The decree further enjoined ASCAP from entering into or recognizing any license agreement which discriminated in price or terms between licensees similarly situated, from refusing to issue per piece licenses to any user other than broadcasters, and from restricting the performance rights of any licensee merely to exact additional compensation.

Significant internal changes in structure and operation were also ordered. ASCAP was required to select its board of directors by a membership vote in which all author, composer, and publisher members were to have the right to participate, the number of votes of any member being determined by his classification in the Society (i.e., his status as to distribution of revenue). Distribution of revenue was ordered to be made only on the basis of the number, nature, character, and prestige of the compositions written or published by each member, the length of time during which the composition has been in the ASCAP repertory, and the commercial popularity of the compositions. Also, membership could only be restricted to professional authors and composers of music who had had one or more compositions regularly published.

Finally, the decree provided that, for purposes of enforcement of its terms, representatives of the United States Department of Justice should have reasonable opportunity to examine all of ASCAP's books and records and to interview all of its employees and officers.

\footnotetext{
${ }^{10}$ Reported in 1940-1943 Trade Cas. 56,104 (S.D.N.Y. 1941).
} 


\section{The Aiden-Rochelle Case}

The close of the consent decree proceedings ended the dispute between ASCAP and the radio broadcasters. ASCAP's peace was shortlived, however. Shortly after the entry of the consent decree of I94I, serious diffculties arose between ASCAP and a group of motion-picture theater owners. ${ }^{20}$

With the introduction of sound into motion pictures, the motionpicture industry had become interested in ASCAP, which then controlled the great bulk of copyrighted music suitable for synchronization with motion pictures. The policy of ASCAP was to reserve the performance rights in such motion-picture music, licensing only the synchronization rights to the producers. The performance rights to ASCAP music were licensed to individual theater owners, who had to obtain a license in order to show movies which contained ASCAP music. ${ }^{21}$

Objecting to this policy, over 150 theater owners instituted an action under the Clayton Act in 1942 for treble damages and for an injunction, alleging that ASCAP had violated the federal antitrust laws. This suit was discontinued, however, until 1947, when ASCAP announced a new method for computing license fees for theater-exhibitors. The proposal, which would have effected an increase in all fees, in some cases from I 200 to I 500 percent, involved computation of the fee on the basis of the theater admission price rather than seating capacity, as had previously been the case. ASCAP contended that this method would merely pass on to its members a reasonable portion of the profits accruing from increased theater admission prices. The theater owners did not agree and, even though ASCAP withdrew its proposal, rejuvenated the 1942 action and carried it to a final decision.

${ }^{20}$ Although not directly connected with the legal dispute between ASCAP and the theater owners, the relations between ASCAP and motion-picture producers had been far from harmonious. In 1924, the producers bad spent $\$ 100,000$ in an attempt to organize their own counterpart performing-right society, but had failed. See Comment, 25 IND. L.J. 168,173 (1950). Thereafter, many producers joined the ASCAP organization by purchasing music publishing firms which were members of ASCAP. By 1950, the producers represented a substantial part of the publisher membership of ASCAP, sharing in the $1 / 2$ of the net proceeds which went to the publishers to the extent of $37 \%$. Timberg, supra note 12, at 297 .

${ }_{21}$ The fact that motion picture producers insisted upon acquiring both the synchronization and the performance rights in motion picture music composed by nonASCAP members indicates that this was a premeditated policy forced on ASCAP by the producers. In either case, of course, the cost of the performing right license was borne ultimately by the theater exhibitor. 
The resulting decision, Alden-Rochelle, Inc. v. ASCAP, ${ }^{22}$ held that ASCAP had violated the antitrust laws in its dealings with the exhibitors, although the court ruled that the plaintiffs had failed to prove that they had been injured. ${ }^{23}$ The court's opinion contained a sweeping denunciation of ASCAP's structure and activities.

Almost every part of the Ascap structure, almost all of Ascap's activities in licensing motion picture theaters, involve a violation of the anti-trust laws. ${ }^{24}$

....

That Ascap is a monopoly, within the language of $\S 2$ of the anti-trust laws, was clearly established at the trial..$^{25}$

The combination of the members of Ascap in transferring all their non-dramatic performing rights to Ascap, is a combination in restraint of interstate trade and commerce, which is prohibited by $\S \mathrm{I}$ of the anti-trust laws. It restrains competition

2280 F. Supp. 888 (S.D.N.Y. 1948).

${ }^{23}$ The injunctive relief granted in the decision of the case was limited to the specific practices complained of by the motion picture exhibitors. The decree ordered ASCAP to divest itself of all rights of public performance in compositions which had already been synchrouized with movies, to refram from acquiring such rights in any such compositions, to refrain from refusing to grant such rights to motion picture producers in future cases of synchronization, to refrain from licensing such rights to auyone other than motion picture producers, and to refram from conspiriug with motion picture producers to force exhibitors to obtain performing licenses as a condition to the exhibition of licensed motion pictures.

In a subsequeut clarifying opinion, Aldeu-Rochelle, Inc. v. ASCAP, so F. Supp. 900, 902 (S.D.N.Y. 1948), the court explained that all parts of the decree were designed to strike down the means by which ASCAP and its members in combination with motiou picture producers were able to require motion picture exhibitors to obtain ASCAP licenses prior to and as a condition of exhibition of motion pictures contaiuing ASCAP music. The last 4 terms of the decree, the court maintained, were essential to accomplish this end. However, the first, divestiture of performing rights in compositions already synchronized with movies, the court decided, was subject to valid criticism, not because "it goes beyond what may eventually prove to be necessary to protect plaintiffs, but because it naay be difficult to enforce and may lead to soine confusion and a great deal of litigation." Alden-Rochelle, Inc. v. ASCAP, supra, at 903. Accordingly, the decree was ameuded to provide that ASCAP or any of its individual members so long as they remained meinbers should refrain from attempting to euforce the motion picture performing rights of any composition so long as ASCAP remained an illegal combination and monopoly.

${ }^{24}$ Alden-Rochelle, Iuc. v. ASCAP, 8o F. Supp. 888, 893 (S.D.N.Y. 1948).

${ }^{25}$ Ibid. 
among the members of Ascap in marketing the performing rights of their copyrighted works. ${ }^{26}$

The combination of the authors, composers, and publishers in the Ascap organization, their obligations to the association, the rights they conferred on Ascap and the reservations they made in their arrangements with the motion picture producers, have given Ascap the power to fix the prices at which the performing rights are sold to the exhibitors. ${ }^{27}$

The strong language of both Alden-Rochelle opinions portended serious curtailment, if not outright prohibition, of ASCAP's operations in the future. For at the time the opinions were rendered, two antitrust actions had been filed by the Government against ASCAP, one involving its activities with international performing-right societies, the other to amend the consent decree of I94I which regulated ASCAP's domestic activities. Since Alden-Rochelle and Witmark v. Jensen ${ }^{28}$ involved complaints of private parties, their effect was restricted to the limited legal and economic interests of those parties. At the same time, however, these cases disclosed broad legal deficiencies in ASCAP's operation and structure. Moreover, the $194 \mathrm{I}$ consent decree, which covered little more than the antitrust grievances of the radio industry, had become a source of discontent to both users of ASCAP music and members of ASCAP, as the increasing number of complaints to the Department of Justice attested. ${ }^{29}$ It was thus clear that revision of the $194 \mathrm{I}$ decree was necessary to remedy these deficiencies and, as well, to accommodate ASCAP to new developments in the music entertainment field. ${ }^{30}$

\section{ASCAP's International Relatrons}

ASCAP, again not eager to try the cases on the merits under the Sherman Act, entered into two consent decrees. The first, ${ }^{31}$ an independent decree in itself involving ASCAP's international relations, enjoins the Society from interfering with the rights of its nnembers to issue nonexclusive licenses for performance outside the United States. And

${ }^{20}$ Id. at 894 .

${ }^{27} I d$. at 894,895 . This conclusion was endorsed by another federal court shortly after the Alden-Rochelle decision. See Witmark \& Sons v. Jensen, 8o F. Supp. 843 (D.C. Minn. 1948).

\footnotetext{
${ }^{28}$ See note 27 supra.

${ }^{\text {so }}$ See note 2 supra.

${ }^{81}$ United States v. ASCAP, 1950-1951 Trade Cas. 762,594 (S.D.N.Y. 1950).

${ }^{20}$ Timberg, supra note 12, at $30 \mathrm{x}$.
} 
in its relations with foreign performing-rights societies, ASCAP is prohibited from (I) accepting from any such society any license for or assignment of musical performing rights in excess of twelve months' duration; (2) refusing to grant licenses for performing rights to any such society, except where it has breached a substantial term of an existing license or would not capably represent ASCAP in the foreign country; (3) granting any performance license to any foreign society which does not expire at least six months following the expiration of any license granted to it by the foreign society; (4) negotiating for the issuance of licenses to any foreign society while also negotiating for issuance to ASCAP of a license from such foreign society; ${ }^{32}$ (5) attempting to prevent or to discriminate against any foreign society issuing nonexclusive, nondiscriminatory licenses to any performing-right society other than ASCAP; and (6) conditioning the licensing of any foreign society upon the reciprocal licensing of ASCAP by that foreign society.

As to international performing-right societies with which ASCAP may now deal, the decree forbids ASCAP to participate in any way with any international organization which prevents its members from licensing nonmember societies, imposes numerical territorial limitations upon membership, prevents any American society from dealing without restriction with any foreign society, or has the purpose or effect of allocating or restricting territories or otherwise eliminating competition among performing-right societies.

To make the decree effective, ASCAP was ordered to sever all connections with over twenty named foreign societies. Again, as in I94I, the decree provided that the Department of Justice should have reasonable opportunity to examine ASCAP's books and records and to interview its employees and officers for the purpose of securing compliance.

Although this decree prohibited many of ASCAP's former activities, its effect has not been unduly to hamper ASCAP's relations with foreign performing-right societies. ASCAP continues to have certain ex-

${ }^{32}$ The practical effect of this provision is to force ASCAP to negotiate first for the licensing of ASCAP's repertory to the foreign society. Only thereafter can ASCAP negotiate for a performance license of the foreign society's compositions. This provision serves the purpose of preventing ASCAP from coercing a license from the foreign society by the threat of withholding its vast repertory from the foreign society. Finkelstein, Public Performance Rights in Music and Performance Right Societies, 7 CoPYRIGHi Problems ANalized 69, 80 (C.C.H. I95I). 
change difficulties with foreign societies, but in general, its arrangements with such societies operate smoothly within the terms of the decree. ${ }^{33}$

\section{The 1950 Amendment to the Consent Decree of $194 \mathrm{I}$}

The second consent decree $e^{34}$ was a comprehensive amendment to the I94I consent decree. While all the provisions of the I94I decree were preserved or strengthened in the amended consent decree of 1950, the latter, at the same time, added several significant new features.

\section{A. General Provisions of the Decree}

The general provisions of the decree restrain ASCAP from (I) dealing in any copyright performing rights other than on a nonexclusive basis and interfering with issuance of nonexclusive licenses of performing rights by individual members; ${ }^{35}(2)$ discriminating in price or other terms between licensees similarly situated; (3) granting any performing license for a period in excess of five years' duration (except in regard to licensing of motion picture performance rights) $;^{36}$ (4) enforcing motion picture performance rights against any motion picture exhibitor and bringing any action for copyright infringement against any exhibitor relating to such picture performing rights or against any user relating to compositions not contained in ASCAP's official public repertory; (5) restricting any member's right to withdraw from the Society at the end of any fiscal year upon his giving three months' notice and upon his agreeing to honor existing obligations between ASCAP and any of its licensees; ${ }^{37}$ and, finally, (6) exercising any power to restrict public performance for profit by any of its licensees in order to exact additional consideration or to regulate recording fees, unless such restriction is reasonably necessary to protect the compositions involved against indiscriminate performance, or to protect the value of public or

\footnotetext{
Finkelstein, note 32 stupra.

${ }^{34}$ United States v. ASCAP, 1950-195 I Trade Cas. I 62,595 (S.D.N.Y. 1950).

${ }^{35}$ The 1950 decree does not include the conditioning limitations permitted ASCAP under the 1941 decree, which had negated the effect of the prohibition against its acquiring or asserting the exclusive right to license performance.

${ }^{36}$ From a practical economic standpoint, the complete integration of music into motion pictures demands that the performing license in such cases be permanent. In light of the specific restrictions upon ASCAP's dealings with motion picture producers and exhibitors, this exception is necessary from the standpoint of the consistency of the decree.

37 The provision limiting ASCAP's performing licenses in nonmotion-picture cases to 5 years' duration has the effect of making complete each member's right of withdrawal from the Society.
} 
dramatic performing rights therein, or to protect ASCAP's rights in connection with any claim or litigation involving such rights. ${ }^{38}$

\section{B. License Issuing}

The decree regulates ASCAP's licensing policies with respect to three major classes of users of music. First, ASCAP must issue performing right licenses on request to any radio, television, or wire-service network in terms which permit both simultaneous and delayed performances by any or all stations or outlets affiliated with such networks, without requiring a separate license for each station or outlet for such performances. $^{39}$ Second, licenses must also be issued on similar terms to any manufacturer, producer, or distributor of transcriptions intended for radio or television broadcasting, without requiring separate licenses for each broadcasting station for such performance. Finally, ASCAP must issue to any motion-picture producer a single license of motion-picture performance rights covering the entire United States.

The decree then specifically spells out certain limitations and requirements as to the "single" licenses to be issued to the motion-picture producers. The license may relate only to pictures produced or in production within one year of the effective date of the license and may not charge for any performance occurring before the decree. Upon request of the producer, such licenses must be issued on a per film basis for compositions in ASCAP's repertory. The licenses must be negotiated and issued on an individual basis, not on an industry-wide basis. Nor may any member of ASCAP's board of directors participate in such negotiation or issuance or in enforcement of any such license where that member at the time has any direct or indirect pecuniary interest in any producer or its affiliate or subsidiary, or has any contractual relationship with any such producer. ${ }^{40}$

${ }^{38}$ Thus, while individual members' rights are protected against indiscriminant performances, ASCAP is limited to its legitimate function, granting performance licenses, and is prevented from applying pressure to gain advantages as to synchronization and recording rights.

${ }^{30}$ Licensing at the source, provided for in the 1949 decree as to radio, was thus carried over to television, the wire services, and motion pictures. There appear to be no technological or economic reasons why any of these industries should not be included.

${ }^{10}$ This provision obviously is intended to prevent any future conflicts of interest in those cases where ASCAP publisher members are subsidiaries or affiliates of motion picture producers. Section XVII of the decree expressly reserves the right of the Government at any time, within 2 years to move. for modification or vacation of the terms of the decree which regulate the manner of licensing motion picture performance rights. 
ASCAP is further ordered by the decree to grant any user making written application a nonexclusive license of all compositions in the ASCAP repertory. The privilege of "per piece" licensing is retained, but is available only upon written request of the user and approval of the interested ASCAP member.

\section{Setting of License Fees}

In regard to license fees for radio and television broadcasting, ASCAP is enjoined, unless the user expressly desires otherwise, from basing its fees for commercial programs on a percentage of the income which the licensee obtains from programs not performing compositions in the ASCAP repertory. In the case of sustaining programs, ASCAP must vary the fee either according to the number of performances of ASCAP compositions during the term of the license or according to the number of programs on which such compositions are performed. With respect to unlicensed radio or television broadcasters, ASCAP is ordered to issue, upon written request, per program licenses, the fees for which, in the case of commercial programs, are to be expressed in terms of dollars, requiring payment of a specified amount for each program or a percentage of the sum paid by the sponsor of the program to the broadcaster. Fees charged for music used on sustaining programs are likewise to be expressed in terms of dollars or based upon a percentage of the card rate which would have been applicable for use of the broadcasting facilities had the program been commercial.

Where stations have a greater percentage of sustaining programs than of commercial programs, the decree authorizes considerations of the economic situation of such stations, subject to the provisions as to discrimination in fees, in order to give the stations a genuine economic choice between per program and blanket licenses. ${ }^{41}$ In all cases, however, the decree prohibits ASCAP from requiring or influencing prospective licensees to negotiate for a blanket license prior to negotiating for a per program license. The decree also directs ASCAP to expend its best efforts to avoid any discrimination between the fees fixed for various types of licenses that would deprive prospective licensees of a genuine economic choice between the various types.

In order to supplement the provisions requiring compulsory licensing

"The intent here is to protect educational, "good music," and other commercially weak stations. This provision was recently relied on by a group of television broadcasters who mtaintained that their high developmental costs justified a lower fee than that which had been asked by ASCAP. See Timberg, supra note 12, at 3 II. 
of all users, the decree provides an intricate mechanism for court determination of reasonable license fees. Thus, ASCAP must advise each applicant of the fee which it deems reasonable upon receipt of written application for a performing license. If the parties are unable to agree within sixty days, the applicant may apply to the court for determination of a reasonable fee. Upon notice of institution of such a proceeding, ASCAP, in turn, must give notice thereof to the Attorney General..$^{42}$ The burden of proof is placed upon ASCAP to show the reasonableness of the fee requested. During the pendency of the proceedings, the applicant is given the right to use the compositions, and provision is made for the fixing of an interim fee by the court at which a license is to be issued. Upon final determination, the fee set by the court becomes retroactive to the commencement of such interim license, and failure of the applicant to accept such interim license or to pay the interim fee constitutes a ground for dismissal of the application. The final determination of a reasonable fee extends to other applicant licensees similarly situated, although fees determined without court intervention do not have this effect. ${ }^{43}$

\section{ASCAP's Organization}

The amended decree also makes several provisions for altering the internal affairs of ASCAP. Thus, in all-encompassing language, the decree prohibits any officer, director, or agent of ASCAP from participating in or voting on questions relating to transactions between ASCAP and a licensee where there is any pecuniary or contractual relationship between the officer, director, or agent and the licensee. In regard to distribution of revenue, the decree commands that primary consideration be given to objective surveys of performance (other than those sanctioned by the member directly) by or for ASCAP.44

${ }^{2}$ This provision appears designed to make such court determinations of reasonable fees even more distasteful than might otherwise be the case in order to encourage ASCAP both to attempt to offer reasonable fees initially and to agree to reasonable compromises.

${ }^{\text {sa }}$ These provisions for judicial fee fixing are salutary in that they appear to preclude the possibility of future disputes (wherem the public is the real loser) such as those between ASCAP and the radio industry and those between ASCAP and the theater exhibitors. Also, by withdrawing ASCAP's power to fix prices, these provisions prevent ASCAP from taking undue advantage of users, especially small users.

"Without precluding consideration of subjective factors such as seniority or quality, the decree thus orders that an objective standard-commetcial acceptance-be the primary determinative. A background of the special problems here and a description of the current arrangement for distribution of reveuue to members can be found in Timberg, supra note 12, at 316-19. 
The decree also orders an amendment to ASCAP's articles of association to prohibit any member from ever threatening, instituting, or continuing any action for infringement of his copyright performing rights based upon acts occurring prior to the decree or where corresponding synchromzation rights had been granted prior to the decree. The articles must further be amended to prohibit any member, while a member of ASCAP, from granting synchronization rights to any motion-picture producer unless corresponding performance rights are granted therewith in conformity with the decree. ${ }^{45}$

Several provisions of the decree are designed to insure a democratic administration of the affairs of ASCAP and to assure its members an opportunity to protect their rights through fair and impartial hearings based upon adequate information. All members are to have the right to vote in the selection of their representatives to serve on the board of directors, due weight being given to the classification of each member in determining the number of votes accorded him. Further, election of all directors must take place at least every two years, and representation on the board, in so far as possible, is to be given to members with different participation in revenue distribution. The general basis of classification for voting must be available in writing to every member, and every member must be able to appeal his classification to an impartial arbiter. In all proceedings involving such classification, moreover, records must be kept to apprise members of the action taken. ${ }^{46}$ ASCAP must also prepare and maintain for public inspection a list of all musical compositions in its repertory, showing author, composer, and current publisher of each composition.

As under the I94I decree, membership in ASCAP must be open to all composers or authors of professional standing who have had one composition regularly published. Publishers whose musical publications have been distributed on a commercial scale for at least one year and who assume a normal financial risk in the business of music publication must also be admitted to membership in ASCAP. And as in the previous decrees, representatives of the Department of Justice must be given reasonable opportunity to examine ASCAP's books and records and to

\footnotetext{
${ }^{45}$ Thus, the decree prevents individual members from taking advantage of past misuse of power by ASCAP and, as well, from circumventing the spirit of the decree, in regard to performance licensing of motion picture music, by individually splitting synchronization and performance rights.

${ }^{16}$ That these provisions for protection of individual members and minorities in ASCAP have been effective is shown in Timberg, supra note 12, at 314-16.
} 
interview its employees and officers for the purpose of securing compliance with the terms of the decree.

Finally, the court has retained jurisdiction of the case in order to enable either party to make application for further orders or directions, for modification of the decree, for enforcement of its terms, and for punishment of violations. Strong language at the end of the decree reserves the right to the Government to apply to the court at any time after five years from the date of entry for vacation or modification of the decree in any respect, including the dissolution of ASCAP. ${ }^{47}$

\section{An Analysis of the i950 ASCAP Consent Decrees}

The entry of these consent decrees manifests recognition of the inherent value of collective action in the field of copyright licensing and enforcement, and, at the same time, recognition of the necessity of compelling ASCAP to comply with the basic policies of the antitrust laws. In prohibiting restrictive licensing on an international basis with international performing-right societies, the decree has outlawed practices, clearly illegal under the Sherman Act, ${ }^{48}$ which are unnecessary to ASCAP's continued prosperity. ${ }^{49}$ Similarly, in the domestic field, although its powers are sharply restricted, ASCAP retains the effective ability reasonably to enforce the rights of its members.

That ASCAP constituted a monopoly under section two of the Sherman Act so long as it retained effective power to acquire exclusive licenses and arbitrarily to set license fees seems clear, since it thus had power to exclude competitors and to fix prices. ${ }^{50}$ By prohibiting ASCAP from acquiring or dealing with copyright performing rights other than on a nonexclusive basis and interfering with (or conditioning as under the I94I decree) issuance of nonexclusive licenses of these rights by individual members, and by requiring free entry and exit of members to and from the Society, the court has effectively impaired ASCAP's power to exclude competitors. Moreover, the provisions against discrimination in prices or other terms between licensees similarly situated, and against restricting performances by any licensee in order to exact additional consideration, together with the provisions for judicial fee-fixing, have

\footnotetext{
17 The primary source of the commentary in footnotes $32-46$, relating to the 1950 consent decree, has been Timberg, supra note 12.

"See United States v. National Lead Co., 332 U.S. 319 (1947).

to See Finkelstein, supra note 32.

${ }^{80}$ See American Tobacco Co. v. United States, 328 U.S. 781 (1946); United States v. Aluminum Co. of America, 148 F.2d 416 (2d Cir. 1945).
} 
destroyed ASCAP's power to fix prices arbitrarily. Even if ASCAP's monopoly power is not as clear as was suggested in the language of the Alden-Rochelle opinions, ${ }^{51}$ the decrees achieve a salutary effect in barring any attempted acquisition or assertion of such power by ASCAP.

The remaining provisions of the decrees deal with problems under section one of the Sherman Act relative to ASCAP's organization as a copyright pool. ${ }^{52}$ It has been held by the Supreme Court ${ }^{53}$ that the monopolies granted to copyright and patent owners under the law are primarily to encourage development of the arts and sciences and, therefore, that reward to the owners is secondary in importance to the benefit which is to be derived by the public. Accordingly, where patent and copyright owners have undertaken to act beyond the limited grant of the law, the Court has judged their actions in the light of usual antitrust principles. ${ }^{54}$ In cases of pooling arrangements by patent owners, the Court has ruled that while this action is not illegal per se, ${ }^{55}$ the arrangements are to be condemned when the pools are used to abuse the antitrust laws, as by fixing uniform prices or terms for the sale of patented goods. ${ }^{56}$ The same rule has been carried over into the copyright field. ${ }^{57}$

The domestic consent decree of 1950, while not eliminating the pooling aspect of the ASCAP arrangement, has severely limited ASCAP's ability to act as a copyright pool. As stated, the decree attempts to prevent unreasonable action aimed at excluding competitors and at arbitrarily fxing prices. The ASCAP pooling arrangement gives increased power to members with larger copyright holdings, so that joint action by a few such members may determine the course of dealing

${ }^{51}$ See Shull, Collecting Collectively: ASCAP's Perennial Dilemma, 7 CopYrichT LAw SYMPosium 35, 50 (1956).

${ }^{59}$ Patent or copyright pools result from the mutual exchange or acquisition of patent or copyright rights from others. OPPENHEIM, CASES on FEDERAL ANT1-Trust Laws 443 (1958). An organization such as ASCAP, where numerous copyright holders assign their rights to a central licensing agency, would seem to be an example of the purest form of the pooling device.

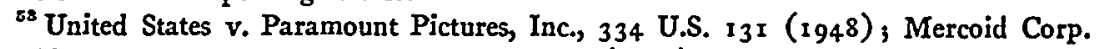
v. Mid-Continent Investment Co., 320 U.S. 661 (1944).

c4 United States v. Paramount Pictures, Inc., 334 U.S. 13I (1948); United States y. Lime Material Co., 333 U.S. 287 (1948); Interstate Circuit, Inc. v. United States, 306 U.S. 208 (1939); United States v. General Electric Co., 272 U.S. 476 (1926).

${ }^{5 s}$ Standard Oil Co. (Indiana) v. United States, 283 U.S. 163 (I93I).

${ }^{50}$ United States v. National Lead Co., 332 U.S. $3^{19}$ (1947); Hartford-Empire v. United States, 323 U.S. 386 (1945).

${ }^{67}$ United States v. Paramount Pictures, Inc., 334 U.S. I 31 (1948). 
of the entire society in any given matter and, moreover, may do so in a manner unreasonably detrimental to the interests of other members, users, competitors, and the public. For this reason, the decree prohibits participation in any dealings between ASCAP members and licensees who share a common pecuniary interest. For this reason also, distribution of revenue to the two groups of members is required to be based primarily upon objective surveys of commercial performances of ASCAP compositions and upon the members' classification in the Society. To insure fair and impartial classification, the decree requires a full explanation in writing of the basis of such classification, the maintenance of complete records regarding classifications, and the recognition of the right of members to appeal their classifications to an impartial arbiter.

The provisions requiring compulsory licensing of all users at reasonable fees in the prescribed manner is a device carried over from the patent field, where it is employed in instances where patent grants have been used to violate the antitrust laws. ${ }^{58}$ While ASCAP does not have a history of excluding licensees (indeed, its history shows the opposite tendency), this provision is necessary to avoid future instances of bitter disputes with licensees, especially with radio broadcasters and motionpicture exhibitors.

The decree goes farthest in accommodating ASCAP's position in the provisions relating to the types of licenses required to be granted. "Per piece" licensing is required only upon the request of the user and the approval of the ASCAP member in interest, and it thereby is made secondary in importance to the issuance of blanket licenses. This is true, a fortiori, despite the order of the decree requiring ASCAP to avoid discrimination between the fees for different types of licenses and otherwise to do its best to offer licensees a genuine choice between the different types of licenses. Therefore, it seems clear that these provisions of the decree are compromises of strict application of the antitrust laws. Nothing in the copyright law permits combination of copyright owners for the purpose of setting license fees, nor is such action justified under the antitrust laws, even though the fees set are reasonable. ${ }^{59}$ Moreover, the Supreme Court has expressly asserted that practical difficulties confronting patent or copyright owners cannot justify conduct in violation

\footnotetext{
Bs United States v. National Lead Co., 332 U.S. 319 (1947); Hartford-Empire v. United States, 323 U.S. 386 (1945).

"5 United States v. Socony-Vacuum Co., Inc., 310 U.S. 150 (1940).
} 
of the Sherman Act. ${ }^{60}$ The fact remains, however, that the consent decree of 1950 affirms the propriety of ASCAP's fixing license fees, at least in the first instance and so long as the fees remain reasonable in amount and in application. At the same time, by upholding ASCAP's ability to issue blanket licenses, the decree approves what appears, at least at first blush, to be a tying arrangement of multiple copyrights, which might well have a tendency to exclude from the market music of competing nonmembers and give each member a reward based in part upon the combination with other copyright owners.

As a matter of strict antitrust principle, permitting such an arrangement to continue seems irrational. The Court has indicated in at least one copyright case, however, that a blanket tying arrangement of copyrighted products, if optional, is not necessarily unlawful. ${ }^{61}$ On the other hand, the Court has ruled in patent tie-in cases that an optional quality will not save such an arrangement. ${ }^{62}$ Apparently, the framers of the consent decree have accepted the former principle but, at the same time, have endeavored to encourage individual licensing at a competitive fee.

While thus attempting to mitigate the more objectionable aspects of an ASCAP pooling arrangement, the decree has retained its other, more beneficial features. Not only is blanket licensing of the ASCAP repertory the most economically advantageous arrangement from the standpoint of ASCAP members, but it also permits continuation of an arrangement most advantageous to large music users-retention of the immediate right to use any ASCAP composition, a matter of commercial necessity in the modern entertainment world of round-the-clock performances and all-inclusive tastes. Of course, to the extent that ASCAP is not a complete monopoly, this practical benefit is not entirely present. ${ }^{.3}$

\section{Conclusion}

In the last analysis, it is impossible to escape the conclusion that ASCAP, without express or implied authorization under the copyright

${ }^{60}$ Mercoid Corp. v. Mid-Continent Investment Co., 320 U.S. 66I (1944).

¿2 United States v. Paramount Pictures, Inc., 334 U.S. 13 I (1948).

${ }^{02}$ International Salt Co., Inc. v. United States, 332 U.S. 392 (1947); United Shoe Machinery Corp. v. United States, 258 U.S. 451 (1922).

${ }^{63}$ The practical henefits to be derived from the existence of a complete performing right society monopoly, such as those created by statute in many foreign countries, has led one writer to intimate that the wisest solution to ASCAP's antitrust problems might be to treat the Society as a public utility. See Finkelstein, Anti-Trust Laws and the Arts, supra note 2, at 63. See also Finkelstein, The Composer and the Public Interest, supra note 2 , at 282. 
laws, is, by its very nature, a horizontal price-fixing association of copyright owners dealing, as a matter of apparent absolute commercial necessity, in the licensing of performing rights to all the copyrighted products within its control. But to deny it the ability to act in either of these respects would in reality deny it the ability to exist. Yet, on the other hand, to permit such activity is to condone an extension of the limited monopoly granted copyrights by law.

Recognizing this dilemma, the framers of the consent decrees of 1950 determined that the problems facing owners of musical copyrights were sufficient to justify a relaxed application of the antitrust laws. Although the decrees include several watchdog provisions and leave open the possibility of dissolution if ASCAP attempts to act beyond the limitations imposed, they enable ASCAP to continue to operate effectively in the world of trade and commerce. That the decrees have been successful seems evident from the absence of further antitrust action against the Society since their entry. While ASCAP might most beneficially exist as a public utility, as has been intimated, ${ }^{64}$ it surely was not within the proper sphere of the court so to decide. By rejecting the extremes, the consent decrees of 1950 appear to have made an admirable and thus far effective accommodation of both sets of policies involved in the effective operation of any performing-right society such as ASCAP.

"Ibid. 